\title{
Proceeding
}

6th INSHS International Christmas Sport Scientific Conference, 11-14 December 2011. International Network of Sport and

Health Science. Szombathely, Hungary

\section{Sport volunteerism: a study on volunteering motivations in university students}

HAMIDREZA MIRSAFIAN , AZADEH MOHAMADINEJAD

Faculty of Physical Education and Sport Sciences, Semmelweis University, Budapest, Hungary

\begin{abstract}
Mirsafian $H$, Mohamadinejad A. Sport volunteerism: a study on volunteering motivations in university students. J. Hum. Sport Exerc. Vol. 7, No. Proc1, pp. S73-S84, 2012. Volunteers form an integral part of the sport industry. Recognition of the volunteers' motivations to attract them in sport programs is the aim of each organization. Although several studies have been conducted regarding volunteers in sport, there is not a clear idea about the effective motivational factors on the sport volunteers on different communities. This subject might be due to the effects of social variables on the volunteering motivations. The aim of this study was to analyze the motivational factors in university sport. The samples consist all of the 304 students who participated as volunteers in sport programs at the Iranian universities. For data collection, a structured questionnaire comprising 39 items in the form of seven different factors (material, social, career supportive, purposive, progress and obligation) regarding the motivational factors of sport volunteering was used. The items in the questionnaire were scored on a 5-point Likert-type scale. This study demonstrated that the social and obligation factors were the highest and lowest effective factors on the sport volunteers' motivation. Also, there was a significant difference between the effect of social and career factors in two genders $(P<0.05)$. This means that boys and girls had higher scores in career and social factors. In conclusion it is stated that university students have a large impact on the general ideas at the communities; therefore, promotion of sport volunteering activities at the universities could develop the culture of volunteering in various parts of the communities. Key words: SOCIAL ACTIVITY, CAREER, SELFESTEEM, SPORT EVENT.
\end{abstract}

\footnotetext{
Corresponding author. Faculty of Physical Education and Sport Sciences, Semmelweis University, 1123 Alkotas Street 44. Budapest. Hungary.

E-mail: Mirsafian@gmail.com

6th INSHS International Christmas Sport Scientific Conference, 11-14 December 2011. International Network of Sport and Health Science. Szombathely, Hungary

JOURNAL OF HUMAN SPORT \& EXERCISE ISSN 1988-5202

(c) Faculty of Education. University of Alicante

doi:10.4100/jhse.2012.7.Proc1.09
} 


\section{INTRODUCTION}

Volunteering is a characteristic of many societies since the creation of human community. This stronghold is in the traditional human solidarity. For many decades there have been individuals who have been willing to give their time, effort and resources to help their fellow man (Gaston \& Alexander, 2001). Volunteering has benefits for three different sets of people: the volunteers themselves, the organizations they help, and the communities they volunteer in (Surujlal \& Dhurup, 2008). In almost all modern societies, the most basic of all values is people helping people and, in the process, helping themselves. Volunteering helps to build more cohesive communities through fostering greater trust between citizens and by developing norms of solidarity and reciprocity which are essential to stable communities (Mihajlovic, 2010).

In modern societies, volunteering is a basic form of civic activism. Volunteer work is based on the efficiency of local associations and associations working in the wider area. Volunteer work is represented in a wide range of organizations: sports, humanitarian, religious, social, NGOs, etc.

In this sense, the volunteers undoubtedly represent a significant potential for overall social development. Key features of volunteering are (Buric, 2004):

- Voluntary - volunteer activities are performed voluntarily. In this sense, voluntary work does not include activities that are performed within the compulsory teaching in schools, civil conscription, and unpaid activities under taken by employees of a company in which they were employed.

- Non - payment - voluntary action is not done from a desire for profit. However, this does not mean that the inclusion of volunteers does not entail costs for the person who is engaged in voluntary work organizations. It is believed that the organization is required to cover all the expenses that a person has in relation to the voluntary engagement.

- Mutual - benefit - individuals and organizations must mutually benefit from volunteering (not material benefit (Mihajlovic et al., 2010).

Volunteers are one of the most valuable and important human resources to the sports sector. They have been and will continue to be an integral and indispensable part of the sport industry (Cuskelly, 1998; Green \& Chalip, 1998). This is because they provide both organizational and economic efficiency, bring innovation into an organization by contributing new and fresh ideas and minimize costs involved with sport events through their free labour (Shin \& Kleiner, 2003); and the operational and financial success of many major sports events has become highly dependent on their contribution (Cuskelly et al., 2004).

To elaborate, and provide some background context for this special issue, it seems appropriate to begin by reflecting on the scale and economic impact of sport volunteering.

In Australia and Canada, for example, over 1 million people volunteer for sport organizations, and in England this number reaches 4.5 million; that is equivalent to $10 \%$ of Australians, $5 \%$ of Canadians, and approximately $11 \%$ of the English population. To put those values in further perspective, about one-quarter of all volunteers in Australia (26\%) and England (26.5\%), and one-fifth of volunteers in Canada (18\%) are involved in the sport sector alone (Cuskelly et al., 2006). They also noted that a comparable portion of New Zealand volunteers are involved in the sport sector $(27 \%)$. These values do not include the wealth of volunteers involved in special sport events hosted by communities and countries. Also, it is noted that the 
hours contributed by sport volunteers are equivalent to 98,000, 262,000, and 450,000 full-time paid employees in sport per year in Australia, Canada and England, respectively. It is clear that the sport industry relies on volunteers, and sport volunteers make up a substantial proportion of the voluntary sector (Doherty, 2006); Due to the growth of the sport industry and particularly youth sport programs over the last two decades, organizational need for volunteer labour has increased; however, the number of volunteers has dropped significantly during this time period (Grimm et al., 2006; Coleman, 2002).Therefore, the investigation of the dynamics of volunteer retention is necessary.

Numerous researchers have shown that volunteer motivation plays an important role for individuals who receive no pay, undergo training, contribute time and effort and remain in a volunteer position (Kim \& Chelladurai, 2008; MacLean \& Hamm, 2007). Clary et al. (1998) stated that motivation is behind the reasons, purposes, plans and goals that make people initiate, direct and sustain volunteer actions.

Knoke and Prensky (1984) categorized volunteer motivation into three incentives: utilitarian, affective and normative. Utilitarian incentives refer to the indirect benefits derived through volunteering, such as the knowledge and skills obtained from volunteer work experience.

Affective incentives are defined as the interpersonal relationships gaining from positive social interactions with others, which may include but are not limited to affiliation, prestige, respect, esteem, friendship and sense of connectedness. Normative incentives focus on philanthropic and altruistic motives, which usually include good will, sharing and helping others (Grimm et al., 2006).

Studies of volunteer motivations in sport and recreation settings are relatively recent phenomenon. Caldwell and Andereck (1994) directly adopted the conceptual approach developed by Knoke and Prensky (1984) and categorized volunteer motivations into three categories of incentives: purposive, solitary and material. Purposive incentives include doing something useful and contributing to society. Solidary incentives deal with social interactions and networking opportunities. Material incentives refer to those tangible benefits provided by the organization utilizing the volunteers. Of these three categories, purposive incentives were identified as the strongest volunteer motivation; whereas material incentives were often the least important (Caldwell \& Andereck, 1994). Williams et al. (1995) had similar research findings when studying on the motivation of volunteers in a mega ski event. Supporting the community and the national team were considered most important by volunteers; whereas free tickets and souvenirs were considered the least motivating. By modifying Knoke and Prensky's (1984) three-factor concept, Farrell et al. (1998) developed the Special Event Volunteer Motivation Scale (SEVMS) with four dimensions to study volunteer motivations for working at an elite women's curling competition event: purposive, solitary, external traditions (e.g., family tradition and external influence) and commitments (e.g., the need of personal skills and external expectations for volunteering). In that study, the researchers found that purposive and solitary incentives were primary motives when compared to external traditions and commitments.

While other researchers have studied volunteer motivation based on the incentives and benefits of volunteering, Clary and his colleagues $(1996,1998,1999)$ studied volunteer motivations based on the functional approach, which is of the belief that individuals can engage in the same activity, yet with diverse psychological functions (Katz, 1960, 1956). Based on the perspective of functionalists, individuals volunteer for the same organization or event to satisfy different motivational functions. Clary et al. $(1996,1998,1999)$ identified six functions of volunteer motivation. They include: (a) Values (i.e., humanitarianism or concern for the beneficiary of volunteering); (b) Understanding (i.e., learning knowledge and skills); (c) Social (i.e., concern about relationships with others); (d) Career-related (i.e., professional benefits, such as 
experiencing different career options or building career-related networks); (e) Protective (i.e., ego defence, such as reducing negative feelings or guilt, or to address personal problems); and (f) Enhancement (i.e., psychological growth and development),(Grimm et al., 2006).

Several researches have been conducted related to the subject of motivation of sport volunteers and different groups of people were examined in this respect. University students are one of the groups that have widespread participation in sport voluntary programs. The importance of participation for this group of people to the voluntary activities encourages researchers to fine the factors which are effective to this issue.

Baghery et al. (2010) in their research on the students participated at the sport universities forums indicated the effect of each of the seventh influenced factors on the motivation of volunteers for participating at the sport events. In that study, the material and purposive factures were the most and least effective factors on the students' participation. In other study, there was a significant difference in students' motivation with regards to their genders and study fields. Also, the career and purposive factor were the highest and lowest influenced factors on the motivation of volunteers (Andam et al., 2009). In that study, 360 students from 20 different universities were examined. The material and personal enrichment were the lower effective factors on the volunteers' motivation, respectively.

In the study on the motivational factors of 120 university students in participation as volunteers in university sport programs, personal growth and value were the highest and lowest effective factors on the students' motivations. Also, there was a significant difference between students' genders in social relationships and self-esteem. With regards to the students' study fields, there was an acceptable difference between students studied in sport fields and other students (Moharamzedeh \& Afroozeh, 2007).

With regards to the variation in the results of previous studies, researchers couldn't found the clear answer to this question:" what factors stimulate people for volunteering?" maybe, different variables such as socioeconomic and cultural factors as well as indigenous, ethnic and race characteristics influenced to this issue.

\section{MATERIAL AND METHODS}

The method of this research was survey and researchers planned to analyze the motivational factors of students who were participated as volunteers at the universities sport programs.

\section{Total Sample}

This research was conducted between all of the bachelor and master students at the public universities in Iran who were participated as volunteers in university sport programs at least 4 times in the last 6 months. Four universities were accidentally selected: Isfahan university (more than 1,000 students), Isfahan Medical Science University (more than 7,000 students), Isfahan University of Technology (more than 9,000 students) and Isfahan University of Art (more than 1,000 students).

The Method of Sampling

Owing to the restricted total number of students who were volunteers at sport activities, the research sample comprises all of the volunteers, which were 304 students. 
Instrument

For collecting the data, a standardized questionnaire designed for measuring volunteering motivation was used (Andam et al., 2009). The questionnaire consisted of 39 questions which measure seven different effective factors on the motivation of sport volunteers. Those factors are as follows: Career, Material, Progress, Purposive, Social, Supportive and Obligation. These seven factors are consistent with the presented factors in the different research works (Chun, 2003; Gentile, 2001; Slaughter, 2002; Strigas \& Jackson, 2003); however, are inconsistent with the single-dimensional model of Cnaan and Goldberg (1991), although they used a questionnaire with 28 questions.

This questionnaire was made based on a 5-point Likert scale. The reliability coefficient reported by Andam et al. (2009) was 0.82 . For determination of reliability in the present research, a preliminary study was done on 30 students from three universities. The reliability coefficient of the questionnaire which was measured by Cronbach-alpha was 0.86 .

The Method of analyzing the data

For analyzing the data, the descriptive statistics and inferential methods were used. In the first phase, the descriptive analysis of data was done, and in the second phase, different inferential statistical methods such as Kolmogorov-Smirnov test, Pearson's correlation coefficient, and Friedman's rank test were used. The Kolmogorov-Smirnov test helped researches for approving the normal distribution of data at the society (P-value $>0.05)$. For finding the relationship between the seven aforementioned factors, Pearson's correlation coefficient, and for the ranking of factors, the Friedman's rank test was used.

\section{RESULTS}

The demographic Specifications of the sample are indicated in Table 1.

Table1. The demographic characteristics of volunteer students at the Isfahan universities.

\begin{tabular}{|c|c|c|c|c|c|c|c|c|c|c|c|c|c|}
\hline & \multicolumn{2}{|c|}{ Gender } & \multicolumn{2}{|c|}{$\begin{array}{c}\text { Marital } \\
\text { Status }\end{array}$} & \multicolumn{4}{|c|}{ Distribution of Age } & \multicolumn{5}{|c|}{ Fields of study } \\
\hline & : & 伺 & 章 & 离 & $\begin{array}{l}\vec{a} \\
\stackrel{D}{2}\end{array}$ & $\begin{array}{l}\text { تี } \\
\text { ส̇ }\end{array}$ & $\begin{array}{l}\text { ते } \\
\text { ஸे }\end{array}$ & ?్ & 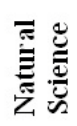 & 言 & 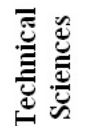 & $\overline{4}$ & 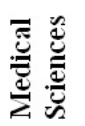 \\
\hline Frequency & $\stackrel{\infty}{\infty}$ & $\stackrel{ \pm}{I}$ & $\underset{\infty}{+\infty}$ & $\stackrel{\sim}{~}$ & ส & $\Xi$ & $m$ & $\bar{\sim}$ & $\infty$ & $\stackrel{g}{q}$ & 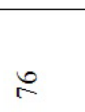 & $m$ & $\stackrel{\infty}{n}$ \\
\hline Percentage & in & 京 & ๙ু & $\stackrel{0}{0}$ & $\stackrel{N}{8}$ & 㐫 & $\vec{d}$ & $\begin{array}{l}\infty \\
\infty \\
\infty\end{array}$ & $\stackrel{a}{\dot{d}}$ & $\overrightarrow{0}$ & $\tilde{\sim}$ & $\stackrel{\infty}{\ominus}$ & 2 \\
\hline
\end{tabular}


As can be seen, most of volunteers were boys and single. Most of volunteers were between 22-25 years old. In addition, the number of students who were studying in the field of natural science was more than other study fields.

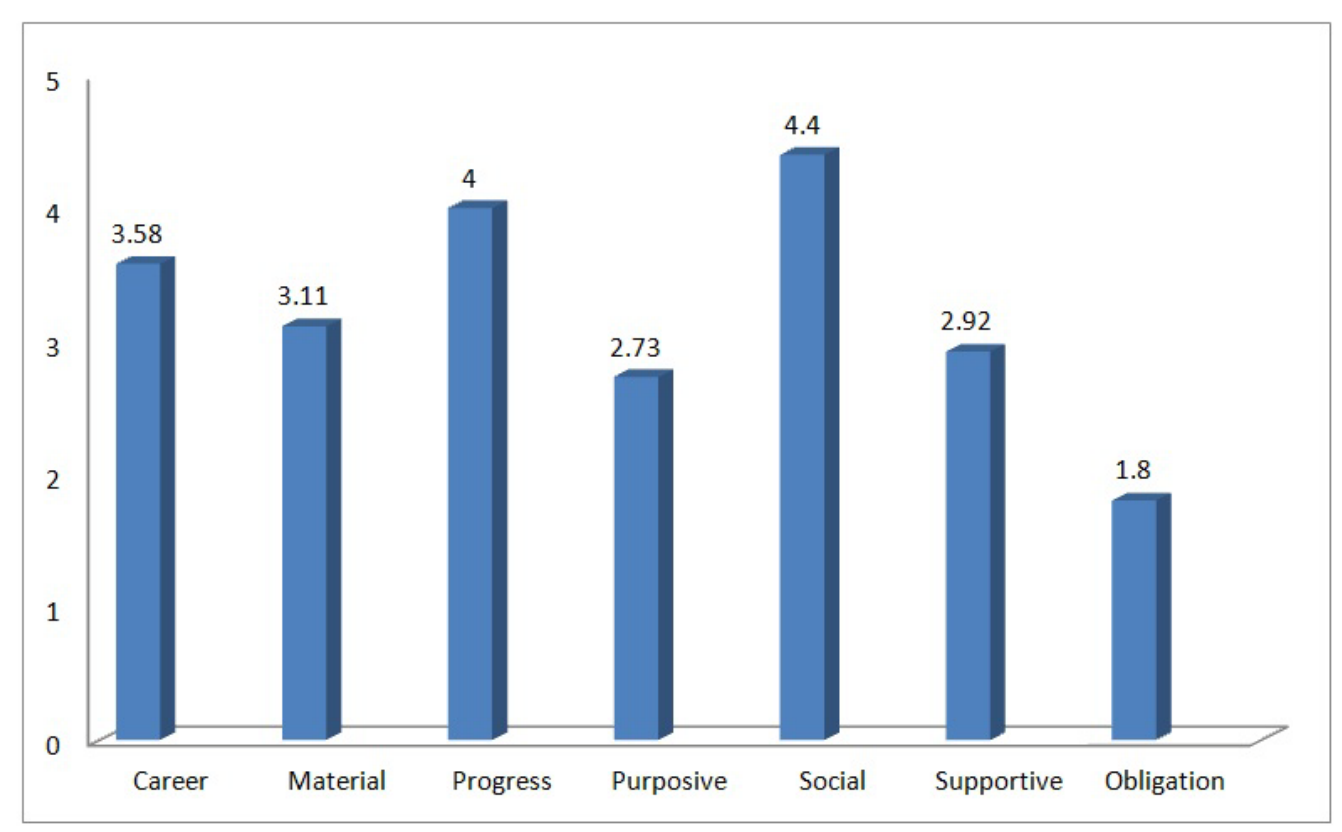

Figure 1. The scores of seven effective factors on the volunteers' motivation.

The roles of each of the seven effective factors in the motivation of volunteers are presented in Figure 1. Those amounts are determined in a 5-point Likert scale. As can be seen, the highest scores related to the social factor (4.4) and the obligation factor was the lowest (1.8).

Table 2. The ranking of seventh effective factors on the volunteers' motivation.

\begin{tabular}{|c|c|c|c|c|c|}
\hline Factors & Rank & Rank's Mean & df & Friedman & $\mathrm{Sig}$ \\
\hline Social & 1 & 6.23 & \multirow[t]{7}{*}{7} & \multirow[t]{7}{*}{361.42} & \multirow[t]{7}{*}{0.001} \\
\hline Progress & 2 & 5.61 & & & \\
\hline Career & 3 & 4.92 & & & \\
\hline Material & 4 & 4.67 & & & \\
\hline Supportive & 5 & 4.33 & & & \\
\hline Purposive & 6 & 3.41 & & & \\
\hline Obligation & 7 & 1.56 & & & \\
\hline
\end{tabular}


In this research, as it was mentioned, the Friedman's rank test was used for ranking the role of each of the seven motivational factors. As it is shown in Table 2, the significant level was 0.001 . This level is lower than the confidence level which was intended for this research (0.05). In other words, there were significant differences between all of seven factors and ranking of them was possible. The results indicated that the rank of each factor was: Social, Progress, Career, Material, Supportive, Purposive and Obligation.

Table 3. Correlation matrix of the seven motivational factors.

\begin{tabular}{|l|l|l|l|l|l|l|l|}
\hline Factor & Career & Material & Progress & Purposive & Social & Supportive & Obligation \\
\hline Career & 1 & & & & & & \\
\hline Material & $\begin{array}{l}\mathrm{r}=0.533 * \\
\mathrm{p}=0.001\end{array}$ & 1 & & & & & \\
\hline Progress & $\begin{array}{l}\mathrm{r}=0.614 * \\
\mathrm{p}=0.001\end{array}$ & $\begin{array}{l}\mathrm{r}=0.663 * \\
\mathrm{p}=0.001\end{array}$ & 1 & & & & \\
\hline Purposive & $\begin{array}{l}\mathrm{r}=0.025 \\
\mathrm{p}=0.82\end{array}$ & $\begin{array}{l}\mathrm{r}=0.453 * \\
\mathrm{p}=0.001\end{array}$ & $\begin{array}{l}\mathrm{r}=0.499 * \\
\mathrm{p}=0.001\end{array}$ & 1 & & & \\
\hline Social & $\begin{array}{l}\mathrm{r}=0.456 * \\
\mathrm{p}=0.001\end{array}$ & $\begin{array}{l}\mathrm{r}=0.285 * \\
\mathrm{p}=0.003\end{array}$ & $\begin{array}{l}\mathrm{r}=0.459 * \\
\mathrm{p}=0.001\end{array}$ & $\begin{array}{l}\mathrm{r}=0.758 * \\
\mathrm{p}=0.001\end{array}$ & 1 & & \\
\hline Supportive & $\mathrm{r}=0.788 *$ \\
$\mathrm{p}=0.001$ & $\begin{array}{l}\mathrm{r}=0.501 * \\
\mathrm{p}=0.001\end{array}$ & $\begin{array}{l}\mathrm{r}=0.397 * \\
\mathrm{p}=0.001\end{array}$ & $\begin{array}{l}\mathrm{r}=0.333 * \\
\mathrm{p}=0.001\end{array}$ & $\begin{array}{l}\mathrm{r}=0.339 * \\
\mathrm{p}=0.001\end{array}$ & 1 & \\
\hline Obligation & $\mathrm{r}=0.569 *$ & $\mathrm{r}=0.654 *$ \\
$\mathrm{p}=0.001$ & $\begin{array}{l}\mathrm{r}=0.773 * \\
\mathrm{p}=0.001\end{array}$ & $\begin{array}{l}\mathrm{r}=0.557 * \\
\mathrm{p}=0.001\end{array}$ & $\begin{array}{l}\mathrm{r}=0.662 * \\
\mathrm{p}=0.001\end{array}$ & $\begin{array}{l}\mathrm{r}=0.621 * \\
\mathrm{p}=0.001\end{array}$ & 1 \\
\hline & $\mathrm{p}=0.001$ & & & & & \\
\hline
\end{tabular}

In Table 3, matrix between each factor with another is presented. As can be seen, there is significant relationship between most of factors; however, the relationship between purposive and career factors is not significant. In the other pair relationships, increase or reduce of one of factors caused the increase or decrease of another. 
The difference between the effect of each of the seven factors on boys and girls was measured by independent t-test. As can be seen, there is a significant difference between the role of social and career factors in two genders. In career factor, the mean of boys' scores was higher, whereas girls' mean scores in social factor were higher.

\section{DISCUSSION}

Volunteers are a crucial component of the work force in the sport industry, particularly at the universities. Understanding the factors that cause and sustain sport volunteerism would assist to the managers for recruiting and retaining them at the sport programs.

The results of descriptive analysis indicated that the ranking of the role of each of the seven effective factors on volunteering motivation was: Social (6.23), Progress (5.61), Career (4.92), material (4.67), Supportive (4.33), Purposive (3.41) and Obligation (1.56).

As can be seen, the result indicated that the social factor was the most effective motivation on volunteers. This factor related to different items that influence on the communication of volunteers with others. This finding is consistent with the result of different researches that accepted the volunteering as a factor for improving the interpersonal relationships (Andam et al., 2009). Hwang (1998) also, in his research indicated that the social relationship was the most effective factor on the students' volunteering motivations. It seems that different social interactions and dating and developing social skills are some of the important and effective volunteering motivations associated with social factor.

With regards to the importance of social exchanges for the young people, especially for students and their special needs for knowing more about themselves and other peoples in the relationships, finding friends, et cetera, volunteer activities could help them to communicate more effectively in relations with other students. On the other hand, with regards to this subject that 38 percent of students were non-locally-based and came from different regions of the country and their families and friends were away from them, their social and emotional needs for establishing relationships and meeting with other students can be explained in the form of volunteering activities.

The second effective factor was progress which is associated with special needs of individual for selffulfilment, self-esteem, success and attention to self-interest and self-benefits. In this regard, Okan and Eisenberg (1992) argued that the special needs of peoples to find themselves as a useful and valuable person in the community is the most important factor for volunteering activities. This motivation helps volunteer to make new beliefs or support the previous positive opinions about the volunteering activities. Developing these beliefs causes that volunteer students develop their personal senses such as self-esteem and self-efficacy. The findings of Martin (1994), and Rumsey (1996) approved our idea. They believed that the dominant motivation in youth in comparison to older people is self-efficacy.

The third effective factor on volunteering motivation in this research was career. This result is consistent with the findings of Gidron (1978) however, Clary et al. (1998) indicated that the effect of this factor is the lowest effect on volunteering motivations. This factor is related to different opportunities which are important and effective for finding careers or gaining experiences related to that. Pi (2001) indicated that development of careers' abilities is one of the important motivational factors for volunteer students and they improve their knowledges and abilities in volunteering activities. In some researches also, this factor was 
one of the most effective factors on the volunteer students (Bagheri et al., 2010; Andam et al., 2009). Volunteering activities provide an opportunity for students for knowing more about their abilities and, finding desire jobs and experience the interesting careers.

Material was the fourth volunteering motivation factor. Expecting benefit and profit instead of offering services is one of the motivational characteristics related to this factor. These rewards can present as material goods, offering services or, even different social situations which convert to the financial bonus. Satisfying the séance of independency is an important motivation for participation of students in volunteering activities. Attention of students to those activities as a student jobs or a small financial source might be motivated them for participation in sport volunteering activities. This result is not consistent with the researches of Caldwell and Andereck (1994), Han (2007) and Andam et al. (2009). In those studies, the material factor stood as the least effective factors on the volunteer motivations however, in the research of Bagheri et al. (2010), that factor was the first effective factor.

The fifth effective factor was supportive. This factor represented the special needs of volunteers for rejecting the negative emotions by participation at the volunteering sport activities. In this subject, the volunteer activities are known as therapeutic roles. With regards to this issue that most of the volunteers in this research were youth under 25 years, participation at the sport volunteering activities could help them to find themselves as effective and valuable individuals at the community and also, support them to overcome to negative emotions specially, on the social relationships. This finding is consistent with the results of Howarth's (1976) study. He indicated that volunteering activities can reduce the anxieties in people. On the other hand, with regards to the effects of the psychological factors on the academic achievements, maybe more consideration to this beneficial aspect of volunteering activities could be helpful to improve the students' academic success.

The sixth volunteering motivational factor was purposive. This factor refers to the volunteer's tendency for effective cooperation and valuable assistance to the organization. As one of the characteristics of youth, especially students is having a strong sense of belonging to their country, city or university, lower effect of this factor might be result of lack of support of volunteering activities by universities managers and lack of value of those activities in the view of them. This result is consistent with the research of Bagheri et al. (2010); however, it was not approved by the findings of Andam et al. (2009). In that research, the purposive factor was the fourth effective factor behind volunteering motivations.

The seventh and lowest volunteering motivation factor was obligation. This factor refers to the others' different expectations (family, friends or university) from the volunteers related to their abilities. This factor is related to volunteers' identity resulting from their university membership. The volunteer in this case wants to find the ways for compensating the assistances and services receiving from university. And the volunteering activity is one of those ways.

The obligation factor was the lowest important factor in this research. This issue could be explained in 2 ways.

1. Lack of students' knowledge related to importance and value of volunteering activities.

2. Lack of coordination between university's expectations and volunteers' abilities and skills. 
In this respect, universities managers can develop the students' participation in volunteering activities by informing them about the universities requirements, persuading them for commitment at the volunteering activities, and by providing an appropriate idea to them as important, valuable and effective members for handling the sport affairs at the university.

In considering the effects of each of seventh factors related to gender, there was a significant difference between social and career factors. This means that, the effects of social and career factor were higher on girls and boys, respectively. This subject can be justified with regards to the social limitation of girls for relationships in the Iranian community, especially in some of traditional and old beliefs families, in compare with boys, and reduction of that limitation at the universities. In this respect, universities managers can improve students' participation, especially girls at the volunteering activities with recognizing their social needs and social interests, and developing their social relationships in grouping activities at the universities. In consideration to the career factor, higher expectations of society from boys as future breadwinners and also, their needs for finding a job after graduation from universities could be the acceptable reasons for difference between two genders.

It should be mentioned that the socio-economic variables could be effective to the motivation of volunteers. Also, the effects of race and ethnicity as well as nativity are important.

All in all, as the university students have a large contribution in volunteering activities in sports programs at the societies, study on volunteering motivations based on various social variables can improve our idea about their requirements and consequently, develop their participation in volunteering sport activities. Also, with regards to the effects of students' ideas on the general opinions of people at the society, participation of students at the volunteering activities can be a large step to spread the culture of volunteering, especially at the sport activities at the society.

\section{REFERENCES}

1. ANDAM R, HEMATINEJAD M, HAMIDI M, RAMNEZANNEJAD R, KAZEMNEJAD A. Study on the volunteering motivations in sport [In Persian]. Olympic Journal. 2009; 3(47):105-116.

2. BAGHERI Y, ASADI H, HAMIDI M. The analyzes of effective factors on volunteering motivations on students' sport affairs at the universities. [In Persian]. Sport Management. 2010; 6:85-91.

3. BURIC L. The SEEYN work camp hand book. 2nd modified ed. Zagreb: Volunteer's Centre; 2004.

4. CALDWELL L, ANDERECK K. Motives for initiating and continuing membership in a recreation related voluntary association. Leisure Sciences. 1994; 16:33-44.

5. CHUN H. A study of volunteers' motivation and satisfaction in the 2002 FIFA World Cup Korea Japan [Master's dissertation]. [Daphne, AL, United States]: United States Sport Academy; 2003.

6. CLARY EG, SNYDER M, RIDGE RD, COPELANDE J, STUKAS AA, HAUGEN J, MIENE P. Understanding and assessing the motivations of volunteers: A functional approach. Journal of Personality and Social Psychology. 1998; 74:1516-1530.

7. CLARY EG, SNYDER M, STUKAS AA. Volunteers' motivations: Findings from a national survey. Nonprofit and Voluntary Sector Quarterly. 1996; 25:485-505.

8. CLARY EG, SNYDER M. The motivation to volunteer: Theoretical and practical consideration. Current Directions in Psychological Sciences. 1999; 8(5):156-159.

9. CNAAN RA, GOLDBERG-GLEN RS. Measuring motivation to volunteer in human services. Journal of Applied Behavioral Science. 1991; 27:269-284.

10. COLEMAN R. Characteristics of volunteering in UK sport: Lessons from cricket. Managing Leisure. 
2002; 7:220-238.

11. CUSKELLY G, AULD C, HARRINGTON M, COLEMAN D. Predicting the behavioral dependability of sport event volunteers. Event Management. 2004; 9:73-89.

12. CUSKELLY G, HOYE R, AULD C. Working with volunteers in sport, London, United Kingdom: Rout ledge; 2006.

13. CUSKELLY G. Organizational commitment and committee turnover of volunteers in sport. Australian Journal on Volunteering. 1998; 3(2):4-14.

14. DOHERTY A. Sport Volunteerism: An Introduction to the Special Issue. Sport Management Review. 2006; 9:105-109.

15. FARRELL J, JOHNSTON ME, TWYNAM GD. Volunteer motivation, satisfaction, and management at an elite sporting competition. Journal of Sport Management. 1998; 12:288-300.

16. GASTON K, ALEXANDER J. Effective organization and management of public sector volunteer workers: Police Special Constables. International Journal of Public Sector Management. 2001; 14(1):59-74.

17. GENTILE D. Volunteering to coaches: An analysis of youth sport coaches [Doctoral dissertation]. [Boston]: Boston University; 2001.

18. GIDRON B. Volunteer work and its rewards. Volunteer Administration. 1978; 11:18-32.

19. GREEN C, CHALIP L. Sport volunteers: Research agenda and application. Sport Marketing Quarterly. 1998; 7(2):14-23.

20. GRIMM J R, DIETZ N, FOSTER-BEY J. Volunteer growth in America: A review of trends since 1974. Corporation for National and Community Service. 2011 Sep 9. Available from: http://www.nationalservice.gov/pdf/06_1203_volunteer_growth.pdf. 2006.

21. HAN K. Motivation and commitment of volunteers in a marathon running event [Doctoral dissertation]. [Florida]: The Florida state University; 2007.

22. HOWARTH E. Personality characteristics of volunteers. Psychological Reports. 1976; 38: 855-858.

23. HWANG YM. Factors affecting the selection process and job satisfaction at college volunteer in youth service organizations [Master dissertation]. [Taiwan]: University of national Taiwan Norman; 1998.

24. KATZ D. The functional approach to the study of attitudes. Public Opinion Quarterly. 1960; 24:163204.

25. KIM M, CHELLADURAI P. Volunteer preferences for training influences of individuals difference factors. International Journal of Sport Management. 2008; 9(3):233-249.

26. KNOKE D, PRENSKY P. What relevance do organization theories have for volunteer associations? Social Science Quarterly. 1984; 65:3-20.

27. MACLEAN J, HAMM S. Motivation, commitment, and intentions of volunteers at a large Canadian sporting event. Leisure/Loisir: Journal of the Canadian Association for Leisure Studies. 2007; 13:523-556.

28. MARTIN MW. Virtuous giving: Philanthropy, voluntary service, and caring. Bloomington, IN. Indiana University Press. 1994.

29. MIHAJLOVIC M, KOMNENIC N, KASTRATOVIC E, CILERDZIC V. Volunteers in sport organizations. Sport Management International Journal. 2010; 6(2).

30. MOHARAMZEDEH M, AFROOZEH MS. Study on the volunteering motivational factors at the university sport [In Persian]. Study In Sport Sciences. 2007; 19:143-156.

31. OKAN MA, EISENBERG N. Motives and intent to continue organizational volunteering among resident of a retirement community area. Journal of community psychology. 1992; 20:183-187.

32. PI LL. Factors affecting volunteerism for international sport events in Taiwan, Republic of China [Doctoral dissertation]. [Daphne, AL]: United States Sports Academy; 2001. 
33. RUMSEY D. Motivational factors of older adult volunteers [Doctoral dissertation]. [Moscow]: University of Idaho; 1996.

34. SHIN S, KLEINER BH. How to manage unpaid volunteers in organizations. Management Research News. 2003; 26(2/3/4):63-71.

35. SLAUGHTER L. Motivation of long term volunteers at events. Events and Place Making. Australian Centre for Event Management. 2002; 232-252.

36. STRIGAS AD, JACKSON EN. Motivating volunteers to serve and succeed: design and results of a pilot study that explores demographics and motivational factors in sport volunteerism. International Sports Journal. 2003; 7(7):111-123.

37. SURUJLAL J, DHURUP M. Volunteers' perceptions of benefits derived from volunteering: An empirical study. South African Journal for Research in Sport, Physical Education and Recreation. 2008; 30(1):105-116.

38. WILLIAMS PW, DOSSA KA, TOMPKINS L. Volunteerism and special event management: A case study of Whistler's Men's World Cup of Skiing. Festival Management \& Event Tourism. 1995; 3:8395. 